\title{
TUBERKULIN SKIN TEST DETEKSI LATENT TUBERCULOSIS INFECTION PADA PETANI KARET DI KABUPATEN BENGKULU TENGAH
}

\author{
Handi Rustandi, Dwi Wulandari \\ Fakultas Ilmu Kesehatan Universitas Dehasen Bengkulu \\ Email: handi@unived.ac.id
}

\begin{abstract}
ABSTRAK
Tuberkulosis paru masih menjadi masalah kesehatan di dunia. Indonesia menduduki peringkat tiga dunia di tahun 2012. Target nasional Case Detection Rate pada tahun 2018 adalah 70\%, pencapaian Provinsi Bengkulu sebesar 46\% masih berada di bawah target nasional saat ini. Kabupaten Bengkulu Tengah merupakan salah satu kabupaten di provinsi bengkulu yang tiap tahun terjadi peningkatan kejadian TB. Pada tahun 2015, sebanyak 44 penemuan kasus TB positif, dan meningkat pada tahun 2016 sebanyak 64 penemuan kasus yang terdeteksi TB positif dari 22 Puskesmas yang ada. Tujuan penelitian untuk mengetahui adanya Latent Tuberculosis Infection melalui Tuberkulin Skin Test pada petani karet Kecamatan Talang Empat Kabupaten Bengkulu Tengah Provinsi Bengkulu. Metode yang digunakan dalam penelitian ini adalah deskriptif analitik, dengan sampel sebanyak 100 responden. Metode pengambilan sampel menggunakan random sampling. Variabel penelitian ini adalah variabel independen (Tuberkulin Skin Test) dan variabel dependen (deteksi Latent Tuberculosis Infection). Analisis data dilakukan dari analisis univariat. Hasil penelitian menunjukan sebanyak 31 (31\%) responden dengan Tuberkulin Skin test Positif, sebanyak 64 (64\%) responden dengan pendidikan terakhir SMA/SMK, sebanyak 63 (63\%) responden dengan Umur 20-50 Tahun, sebanyak 66 (66\%) responden dengan Jenis kelamin Laki-laki. Disarankan kepada Pihak Puskesmas dan Dinas kesehatan Kabupaten Bengkulu tengah untuk melakukan pemeriksaan lebih lanjut terkait TB Paru pada petani Karet Kecamatan Talang Empat Kabupaten Bengkulu tengah.
\end{abstract}

\section{ABSTRACT}

Tuberculosis is still a health problem in the world. Indonesia was third ranked in the world in 2012. The national target of Case Detection Rate in 2018 was 70\%, Bengkulu Province's achievement of $46 \%$ is still below the current national target. Bengkulu Regency is one of the regencies in Bengkulu Province which has an increase in TB incidence each year. In 2015, there were 44 positive $T B$ case findings, and increased in 2016 by 64 case finding detected by positive TB from 22 existing Puskesmas. The purpose of this study was to determine the presence of Latent Tuberculosis Infection through Tuberculin Skin Test in rubber farmers in Talang sub-district, Bengkulu Tengah regency, Bengkulu Province. The research method used descriptive analytic, with a sample of 100 respondents. Sampling method was used random sampling. The variables of this study were independent variables (Tuberculin Skin Test) and dependent variable (detection of Latent 
Tuberculosis Infection). Data analysis was performed from univariate analysis. The results showed that 31 (31\%) respondents with Positive Tuberculin Skin Test, 64 (64\%) respondents with a high school/vocational high school education, 63 $(63 \%)$ respondents were aged 20-50 years, 66 (66\%) respondents were Male Gender. It is recommended to the Puskesmas and the health service center of Bengkulu regency to carry out further examinations related to tuberculosis in Rubber farmers in Talang Empat District, Bengkulu Regency.

\section{PENDAHULUAN}

Penemuan kasus baru pasien tuberkulosis dilakukan dengan berbagai macam penemuan baik secara pasif, maupun secara aktif. Seseorang dapat tertular tuberkulosis selain karena konsentrasi kuman yang terhirup oleh manusia, lama kuman yang terhirup, virulensi kuman yang masuk dalam saluran pernapasan, jenis pekerjaan, serta umur yang juga dipengaruhi oleh beberapa faktor keadaan gen dari orang tersebut. Tidak semua kuman tuberkulosis yang masuk dalam tubuh dapat menyebabkan seseorang sakit, hal ini tergantung dari kerentanan tubuh sebagai akibat interaksi beberapa faktor di dalam tubuh yang dapat menjadi salah satu faktor pencetus misalnya status gizi, imunisasi, pekerjaan, kepadatan hunian dan gen individu tersebut (WHO, 2011).

Tuberkulosis paru merupakan masalah dunia yang terus terjadi dengan peningkatan prevalensi temuan kasus baru tiap tahun yang terus meningkat. Indonesia menempati peringkat ke tiga di dunia pada tahun 2012. Target nasional Case Detection Rate tahun 2018 adalah $70 \%$, sedangkan pencapaian Provinsi Bengkulu hanya sebesar $46 \%$ jauh dibawah target nasional. Menurut data World Health Organization (WHO) hasil dari Annual Risk of Tuberculosis Infection (ARTI) di Indonesia berkisar antara 1-3\%, yang berarti 10-30 (sepuluh sampai tiga puluh) orang dari 1000 penduduk berisiko terinfeksi tuberkulosis setiap tahun, sehingga perlu dilakukan penelitian dan pengkajian secara khusus. Tuberculosis merupakan salah satu penyakit menular yang menjadi salah satu prioritas pengendalian sehingga Masuk dalam salah satu komitmen Sustainable Development Goals (SDGs). Kabupaten Bengkulu tengah merupakan salah satu Kabupaten di Provinsi Bengkulu yang tiap tahun terjadi peningkatan kejadian $\mathrm{TB}$, di tahun 2015 sebanyak 44 temuan kasus TB Positif, dan terjadi peningkatan di tahun 2016 sebanyak 64 temuan kasus TB Positif dari 22 Puskesmas yang ada (Dinas Kesehatan Bengkulu Tengah, 2017). Mayoritas mata pencarian masyarakat di Kecamatan Talang Empat, Kabupaten Bengkulu Tengah adalah sebagai petani karet, beberapa penyakit yang sering dikeluhkan pada petani karet di pelayanan kesehatan Kabupaten Bengkulu Tengah ditemukan penyakit infeksi paru pada $26 \%$ petani karet yang berkunjung ke Puskesmas, hal tersebut disebabkan karena perilaku hidup yang cenderung tidak memperhatikan aspek kesehatan terutama kesehatan saluran pernapasan, serta beberapa faktor lain seperti terpapar langsung dengan debu, asap rokok, asap pabrik karet, pupuk getah karet maupun debu yang langsung masuk saat proses 
pengikisan batang karet, beberapa faktor pencetus diatas dapat menjadi jalan masuknya mikroorganisme pathogen penyebab beberapa penyakit saluran pernapasan salah satunya adalah Mycobacterium Tuberculosis.

Dari beberapa data pendukung diatas, peneliti memiliki optimisme yang tinggi dalam penemuan kasus baru, melalui deteksi dini tuberkulosis di dunia, negara Indonesia, serta khususnya Provinsi Bengkulu penemuan kasus tubercolosis sudah dalam kategori cukup meski dibawah target nasional yaitu 46\%, sehingga dibutuhkan analisis dan penemuan faktor resiko baru dalam penemuan kasus tubercolosis paru, karena diperkirakan masih banyak kasus tuberkulosis yang belum ditemukan disebabkan beberapa faktor seperti kurang pengetahuan terkait manifestasi penyakit, jarak layanan kesehatan, faktor ekonomi, maupun peran serta keluarga. Sehingga penetapan suatu kebijakan baru di dalam penemuan kasus tuberkulosis di masyarakat dipandang perlu dilakukan guna deteksi dini sehingga dapat dilakukan pengobatan segera, guna menekan angka kejadian yang meningkat tiap tahunnya (Drapper \& Dafee, 2005).

Salah satu metode yang dapat digunakan dalam menilai infeksi TB laten yang ada didalam tubuh manusia (Latent Tuberculosis Infection) adalah dengan uji tuberkulin atau sering dikenal sebagai mantoux test. Uji tuberkulin ini digunakan sekitar 1 abad untuk melakukan deteksi dini atau diagnosis infeksi TB pada seseorang dengan mengukur dan melihat respons hipersensifitas tipe lambat 48-72 jam setelah suntikan intradermal PPD (test Mantoux) pada seseorang dengan faktor resiko (Martin \& Lazarus, 2000).

Diharapkan hasil penelitian tersebut dapat menjadi data yang berguna untuk pihak Kabupaten dan Provinsi, dalam melakukan penanganan lebih lanjut pada temuan kasus, dan berguna untuk penelitian selanjutnya serta mampu mendasari kebijakan maupun intervensi yang akan dilakukan, sekaligus deteksi pada objek penelitian.

\section{METODE PENELITIAN}

Penelitian ini mengunakan metode deskriptif analitik yaitu dengan melihat gambaran kejadian Latent Tuberculosis Infection pada petani karet di Kabupaten Bengkulu Tengah. Populasi dalam penelitian ini adalah seluruh petani karet yang tinggal di Kecamatan Talang Empat Kabupaten Bengkulu Tengah yang berjumlah 654 orang. Sampel dalam penelitian ini adalah petani karet aktif yang tinggal di Kecamatan Talang Empat Kabupaten Bengkulu Tengah sebanyak 100 sampel dengan menggunakan teknik random sampling Karakteristik sampel yang harus dipenuhi adalah petani karet aktif di Kecamatan Talang Empat Kabupaten Bengkulu Tengah, telah menjadi petani karet minimal 2 tahun, bersedia menjadi responden. 


\section{HASIL}

Hasil penelitian dapat dilihat pada tabel berikut:

Tabel 1. Hasil Pemeriksaan Laten Tubercolosis Infection Pada Petani di Kecamatan Talang Empat Kabupaten Bengkulu Tengah Tahun 2019

\begin{tabular}{cccc}
\hline No & Hasil Pemeriksaan & Frekuensi (F) & Persentase (\%) \\
\hline 1 & Positif & 31 & 31 \\
\hline 2 & Negatif & 69 & 69 \\
\hline Total & 100 & 100 \\
\hline
\end{tabular}

Berdasarkan tabel 1 diketahui dari 100 responden sebanyak 69 (69\%) responden dengan tuberkulin skin test negatif, 31 (31\%) responden dengan tuberkulin skin test positif.

Tabel 2. Distribusi Frekuensi Pendidikan pada Petani di Kecamatan Talang Empat Kabupaten Bengkulu Tengah Tahun 2019

\begin{tabular}{clcc}
\hline No & Pendidikan & Frekuensi (F) & Persentase (\%) \\
\hline 1 & SMA/SMK & 64 & 64 \\
\hline 2 & SMP/MTSN & 28 & 28 \\
\hline 3 & SD & 8 & 8 \\
\hline Total & 100 & 100 \\
\hline
\end{tabular}

Berdasarkan tabel 2 diketahui dari 100 responden sebanyak 64 (64\%) responden dengan pendidikan terakhir SMA/SMK, 28 (28\%) responden dengan pendidikan terakhir SMP/MTSN, dan $8(8 \%)$ responden dengan pendidikan terakhir Sekolah dasar (SD).

Tabel 3. Distribusi Frekuensi Umur pada Petani di Kecamatan Talang Empat Kabupaten Bengkulu Tengah Tahun 2019

\begin{tabular}{clcc}
\hline No & \multicolumn{1}{c}{ Umur } & Frekuensi (F) & Persentase (\%) \\
\hline 1 & $20-50$ Tahun & 63 & 63 \\
\hline 2 & $>50$ Tahun & 37 & 37 \\
\hline Total & & 100 & 100 \\
\hline
\end{tabular}

Berdasarkan tabel 3 diketahui dari 100 responden sebanyak 63 (63\%) responden dengan Umur 20-50 Tahun, 37 (37\%) responden dengan Umur > 50 Tahun.

Tabel 4. Distribusi Frekuensi Jenis Kelamin pada Petani di Kecamatan Talang Empat Kabupaten Bengkulu Tengah Tahun 2019

\begin{tabular}{cccc}
\hline No & Jenis Kelamin & Frekuensi (F) & Persentase (\%) \\
\hline 1 & Perempuan & 34 & 34 \\
\hline 2 & Laki-laki & 66 & 66 \\
\hline Total & 100 & 100 \\
\hline
\end{tabular}


Berdasarkan tabel 4 diketahui dari 100 responden sebanyak 66 $(66 \%)$ responden dengan Jenis kelamin Laki-laki, $34 \quad$ (34\%) responden dengan Jenis Kelamin Perempuan.

\section{PEMBAHASAN}

Penyakit tuberkolosis disebabkan karena masuknya kuman Mycobacterium tuberculosis dalam tubuh seseorang, kuman ini merupakan kuman basil tahan asam. Kuman Mycobacterium Tuberculosis menyerang paru maupun jaringan tubuh lainnya. Mycobacterium berbentuk batang dan bersifat aerobik obligat. Manusia merupakan host utama, kuman ini dapat berkembang biak secara cepat dalam tubuh manusia. Ada beberapa faktor penyebab terjadinya transfer kuman Mycobacterium Tuberculosis, diantaranya adanya keluarga yang terinfeksi kuman Mycobacterium Tuberculosis, pekerjaan, usia, jenis kelamin, lingkungan dan kepadatan penduduk.

Salah satu tes yang dapat dilakukan adalah tes kulit tuberculosis (TBC) atau Tuberculin Skin Test, kadang-kadang disebut "Mantoux" adalah cara yang sangat mudah dan tidak berbahaya. Tujuan pemeriksaan ini untuk mengetahui apakah seseorang terkena infeksi TBC laten. Ada dua tahap TBC. Kedua tahap ini dapat disembuhkan dengan obat. Ketika kuman TBC pertama kali memasuki tubuh, akan menyebabkan infeksi TBC laten. Tanpa pengobatan, infeksi TBC laten dapat menjadi penyakit TBC aktif. Siapa pun dapat tertular TBC karena kuman ini dapat menginfeksi dari satu orang ke orang lainnya melalui udara. Sebuah tes kulit TBC
("Mantoux") dapat menunjukkan apakah seseorang terkena infeksi TBC laten. seseorang dapat terkena infeksi TBC laten jika pernah menghabiskan waktu dekat seseorang yang terkena penyakit TBC aktif.

Petugas layanan kesehatan akan menggunakan sebuah jarum kecil untuk menyuntikkan cairan tes yang tidak berbahaya (yang disebut tuberculin) di bawah kulit lengan. Tes ini "positif" jika ada benjolan berukuran tertentu di tempat cairan disuntikkan. Ini berarti pasien mungkin terinfeksi kuman TBC dalam tubuh. Kebanyakan orang yang hasil tes kulitnya positif terkena infeksi TBC laten. Untuk memastikan, tenaga kesehatan akan memeriksa pasien dan meminta menjalani foto thorax. Tes disebut "negatif" jika tidak ada benjolan (atau benjolannya sangat kecil) di tempat cairan disuntikkan.

Hasil penelitian menunjukan bahwa $31 \%$ petani karet memiliki hasil Tuberkulin Skin test positif, berdasarkan teori hal ini dapat terjadi karena responden dengan perkerjaan petani karet cenderung berada di tempat - tempat yang kotor sehingga menyebabkan sistem pernapasan mereka mudah terganggu. Selain itu aroma karet yang menyengat, dapat mempengaruhi sistem pernapasan pada petani. Hal ini dapat memicu terjadinya TBC pada petani.

Beberapa faktor yang dapat menjadi faktor risiko kejadian penyakit tuberkulosis paru diantaranya yaitu faktor kependudukan (jenis kelamin, umur, status gizi perorangan, perandan motivasi keluarga, tingkat pendapatan keluarga, tingkat pendidikan seseorang), faktor lingkungan rumah dan lingkungan 
kerja (luas ventilasi, kepadatan hunian, intensitas pencahayaan yang masuk ke dalam rumah, jenis lantai, kelembaban dalam rumah, suhu lingkungan rumah dan jenis dinding rumah), perilaku dalam menjaga kesehatan (kebiasaan membuka jendela setiap pagi, kebiasaan menjaga kebersihan dan kebiasaan merokok) dan riwayat kontak dengan penderita

Mycobacterium

Tuberculosis (Umar Fahmi Achmadi, 2005, Kemenkes RI, 2010).

Hasil lainnya diketahui sebanyak 64 (64\%) responden dengan pendidikan terakhir SMA/SMK, 28 (28\%) responden dengan pendidikan terakhir SMP/MTSN, dan 8 (8\%) responden dengan pendidikan terakhir Sekolah dasar (SD). Hasil penelitian Sumarmi dan Duarsa (2014) di Puskesmas Kotabumi II, Bukit Kemuning dan Ulak Rengas Kab. Lampung Utara menunjukkan bahwa ada perbedaan proporsi kejadian TB Paru BTA positif antara penderita yang berpendidikan rendah dengan penderita yang berpendidikan tinggi. Hasil ini sejalan dengan teori yang dikemukakan oleh Notoadmojo (2007) yang berpendapat tingkat pendidikan akan mempengaruhi pengetahuan seseorang karena orang yang berpendidikan tinggi biasanya akan lebih mudah menerima informasi atau pengetahuan baru terkait kesehatan, selain itu orang dengan pendidikan tinggi, biasanya lebih cepat mendapatkan informasi terkait kesehatan, baik itu di bangku pendidikan, seminar, maupun media sosial. Responden dengan tingkat pendidikan tinggi lebih perhatian kepada kesehatannya hal ini disebabkan karena informasi terkait kesehatan yang lebih cepat didapatkan sehingga memiliki pengetahuan dalam pencegahan penyakit sejak dini jika dibandingkan orang dengan tingkat pendidikan yang rendah. Responden yang berpendidikan tinggi secara otomatis memiliki tingkat pengetahuan yang lebih luas dan terarah sehingga akan mempengaruhi dirinya dan keluarga dalam memperhatikan status kesehatannya terutama ketika merasakan ada tanda atau gejala sakit akan segera memeriksakan kesehatannya ke pelayanan kesehatan terdekat.

Dilihat dari aspek usia, hasil penelitian diketahui dari 100 responden sebanyak $63 \quad(63 \%)$ responden dengan umur 20-50 tahun, 37 (37\%) responden dengan umur > 50 tahun. Secara teoritis seseorang yang telah berusia $>50$ tahun akan mengalami penurunan sistem imunologis, hal ini dapat mengakibatkan responden dengan usia $>50$ tahun rentan terpapar dengan Mycobacterium Tuberculosis, selain itu banyak faktor lainnya seperti pekerjaan responden, jenis kelamin, kontak dengan pasien dengn TB. Penelitian ini sejalan dengan penelitian yang dilakukan Oleh Bawole (2014) di Kecamatan Likupang Barat Kabupaten Minahasa Utara yang memperoleh hasil responden paling banyak berada pada kelompok umur $\leq 55$ tahun dengan kelompok kasus sebesar 32,7\% dan kelompok kontrol sebesar 32,7\% (Bawole, Rattu, dan Posangi 2014). Penelitian yang lain juga dilakukan oleh Kurniasari, Suhartono dan Cahyo (2012) di Kecamatan Baturetno Kabupaten Wonogiri menunjukkan bahwa pada kelompok umur 56 tahun-65 tahun dengan persentase sebesar $32,4 \%$ yang menderita penyakit Tubercolosis paru, hasil penelitian 
juga menunjukan bahwa kelompok umur ini mendominasi kasus yang ditemukan terkait TB. Namun hasil penelitian tersebut tidak sesuai dengan penelitian yang dilakukan oleh Fahreza, Waluyo dan Novitasari (2012) di Balai Kesehatan Paru Masyarakat Semarang hasil penelitian menunjukkan bahwa pada kelompok kasus dengan BTA positif umur responden yang paling banyak adalah 20-30 tahun. Sehingga dapat disimpulkan bahwa umur sesungguhnya bukan merupakan faktor tunggal terjadinya tuberkolosis paru, namun bnyak faktor resiko pendukung lainnya.

Dari segi jenis kelamin, hasil penelitian diketahui dari 100 responden sebanyak $66 \quad(66 \%)$ responden dengan Jenis kelamin Laki-laki, 34 (34\%) responden dengan Jenis Kelamin Perempuan. Secara teoritis jenis kelamin berpengaruh terhadap kasus Tubercolosis paru, berdasarkan beberapa laporan kasus BTA+ pada laki-laki lebih tinggi dari pada perempuan yaitu hampir 1,5 kali dibandingkan kasus BTA+ pada perempuan. Pada masing-masing provinsi di seluruh Indonesia kasus BTA+ lebih banyak terjadi pada lakilaki dibandingkan perempuan. Lakilaki berisiko lebih besar untuk terkena penyakit TB paru dibandingkan dengan perempuan. Ada beberapa faktor resiko yang terdapat pada laki-laki lebih banyak dibandingkan perempuan seperti merokok, pekerjaan tambang, dan minum alkohol. Merokok, asap, debu dan alkohol dapat mengakibatkan terjadinya penurunan imunitas tubuh sehingga lebih mudah terkena penyakit TB paru (Ruswanto, 2010). Hal ini sesuai dengan penelitian yang dilakukan oleh Lalombo, Palandeng, dan Kallo (2015) yang menyatakan bahwa ada hubungan yang bermakna antara kebiasaan merokok dengan kejadian tuberkulosis paru pada pasien dengan kasus BTA positif. Namun penelitian lain menyatakan bahwa tidak ada hubungan yang bermakna antara jenis kelamin dengan kejadian TB paru BTA positif nilai OR $>1$ (Sumarmi dan Duarsa 2014).

\section{SIMPULAN}

Berdasarkan hasil penelitian dari 100 responden, ditemukan 31 responden $(31 \%)$ dengan hasil Tuberkulin Skin test positif yang terdeteksi yang artinya petani yang terpapar debu pupuk, serbuk pohon karet memiliki resiko terkena bakteri tuberculosis pada petani di kecamatan talang empat Kabupaten Bengkulu Tengah Provinsi Bengkulu.

\section{SARAN}

Disarankan kepada Puskesmas dan Dinas kesehatan Kabupaten Bengkulu Tengah untuk melakukan pemeriksaan lebih lanjut terkait TB Paru pada petani Karet di Kecamatan Talang Empat Kabupaten Bengkulu tengah, guna penemuan kasus baru dan faktor resiko baru, sehingga target nasional dalan Case Detection dapat mencapai $70 \%$.

\section{DAFTAR PUSTAKA}

The tuberkulin (Mantoux) skin test. Available at http://www.nt.gov.au/health /cdc/fact_sheets /tb_skintest_factsheet.pdf. Acessed September 18 2018. 
WHO. 2011. Global Tuberculosis Control 2011. www.who.int.org. Diunduh 05 September 2018.

Dinas Kesehatan Bengkulu Tengah. 2017. Profil Kesehatan Kabupaten Bengkulu Tengah. Dinas Kesehatan:Benteng

Tuberkulin testing. Available at http://www.11openmed.nec. in

/424/01/NPITSH80.0.PDF. Acessed September 23 2018.
Drapper P and Dafee M. The cell envelope of mycobacterium tuberculosis with special reference to the capsule and outer permeability barrier. In : Cole ST, Eisenach KD, Mc Murray DN, Jacobs WR. Eds. Tuberculosis and the tubercle bacillus. Washington: ASM Press; 2005.p.261-85.

Martin G, Lazarus A. Epidemiology and diagnosis of tuberculosis. Postgraduate Medicine. 2000;108(2). 